\title{
Models for Predicting Bulinids Species Habitats in Southwestern Nigeria Using Geographic Information System
}

Opeyemi G. Oso ( $\sim$ opeyemi.immaculate@gmail.com )

University of Ibadan Faculty of Science

Alex Odaibo

University of Ibadan Faculty of Science

\section{Research}

Keywords: Bulinid species, GIS/RS, Schistosomiasis, Nigeria

Posted Date: September 8th, 2020

DOI: https://doi.org/10.21203/rs.3.rs-69331/v1

License: (c) (1) This work is licensed under a Creative Commons Attribution 4.0 International License.

Read Full License 


\section{MODELS FOR PREDICTING BULINIDS SPECIES HABITATS IN SOUTHWESTERN NIGERIA USING GEOGRAPHIC INFORMATION SYSTEM Opeyemi G. Oso $^{1 *}$, Alex B. Odaibo ${ }^{2}$ \\ ${ }^{1,2}$ Parasitology Research Unit, Department of Zoology, University of Ibadan, Ibadan, Nigeria (e- mail: (opeyemi.immaculate@gmail.com ${ }^{1}$, alexodaibo@yahoo.com ${ }^{2}$ ) \\ *corresponding Author}

ABSTRACT

Background: Schistosomiasis prevalence is high in southwestern Nigeria and planorbids of the genus Bulinus had been implicated in the transmission of the disease in the area. The knowledge of species distribution in relation to environmental variables will be auspicious in planning control strategies.

13 Methods: Satellite imagery and geographic information system (GIS) were used to develop models for predicting the habitats suitable for bulinid species. Monthly snail sample collection was done in twenty-three randomly selected water contact sites using standard method for a period of two years. Remotely sensed variables such as Land Surface Temperature (LST), Normalized Difference Vegetation Index (NDVI) were extracted from Landsat TM, ETM+; Slope and Elevation were obtained from digital elevation model (DEM) while Rainfall was retrieved from European Meteorology Research Program. These environmental factors and snail species were integrated into GIS to predict the potential habitats of different bulinid species using exploratory regression models.

Results: The following environmental variables: flat-moderate slope $(0.01-15.83), \mathrm{LST}\left(21.1^{\circ} \mathrm{C}-\right.$ 23.4 $\left.{ }^{\circ} \mathrm{C}\right)$, NDVI (0.19-0.52), spatial rainfall (> 1,569.34 mm) and elevation (1-278 meters) all contributed to the model used in predicting habitat suitable for bulinids snail intermediate hosts. Exploratory regression models showed that LST, NDVI and slope were predictors of B. globosus and B. jousseaumei; elevation, LST, Rainfall and slope were predictors of B. camerunensis; spatial rainfall, NDVI and slope were predictors of B. senegalensis while NDVI and slope were predictors of $B$. forskalii in the area. Bulinids in the forskalii group showed clustering in middle belt and south. The predictive risk map of $B$. jousseaumei was similar to the pattern described for $B$. globosus, but with a high R-square value of $81 \%$.

31 Conclusion: The predictive risk models of bulinid species in this study provided a robust output

32 for the study area which could be used as base-line for other areas in that ecological zone. It will 
be useful in appropriate allocation of scares resources in the control of schistosomiasis in that

34 environment.

Keywords: Bulinid species, GIS/RS, Schistosomiasis, Nigeria.

\section{Introduction}

Schistosome infection cause debilitating illness in millions of children and adult in different part of the world, especially in tropical countries. Freshwater snails continue to play significant role in in the transmission of the infection. Therefore, this freshwater snails need to be scientifically explored extensively (1-3). They invade freshwater bodies where they serve as intermediate host, transmitting several parasites $(4,5)$. Different stages of the life cycle of these parasites are completed in the snail species. These intermediate hosts inhabit a wide range of natural and man-

Studies in Southwestern Nigeria have shown that prevalence of schistosome infection among the inhabitants and snail intermediate hosts is high $(9,10)$. The main stay of schistosome treatment in human is paraziquantel-based therapy; while snail control is almost neglected or perhaps they are considered as an accompanying strategy, most especially in high transmission areas (11). It has been observed that embarking on large-scale control of snails seems to be impracticable, however, identification of areas at high risk and application of long-term effective measure have emerged as a possible way of interrupting schistosome transmission $(12,13)$.

Field epidemiology is often based on the fact that definitive host, snail intermediate hosts and their associated pathogen are associated with certain environmental factors. These environment factors either increase the survival of snail species or inhibit them. (14). However, the development of geographic information system and remote sensing technology have provided more robust way of determining environmental variables which are related to the distribution of snail intermediate

62 There are about forty known genera of planorbids that are found on all continents where 
there are approximately 37 recognized species of Bulinus species (6); however, the specificity of

65 the snail-parasite interaction is such that only certain species are involved in transmission of the parasite. The genus can be further divided into four major groups, namely, Bulinus africanus group, Bulinus forskalii group, Bulinus reticulatus group and Bulinus truncatus/tropicus complex. In each group, there are species that act as intermediate hosts of trematodes in different parts of the world (6). The growing interest in biodiversity and its evaluation has highlighted the importance of species identification (18), but the distribution of these snails is related to available freshwater bodies and suitable environmental factors. To understand the transmission dynamics of schistosome infection in relation to snail intermediate host, it is necessary to have a precise knowledge of prevailing environmental variables in time and space. Geographic Information System (GIS) and Remote Sensing (RS) have proved to be useful for epidemiological research purposes, decision making, planning, management and dissemination of information in time and space. GIS applications related to health have been introduced and used in, for example, the surveillance and monitoring of vector-borne diseases (19-21, 22-24, 25). Remote sensing and GIS have also increased their importance and utility in health-related studies $(26,27,28,29)$. Environmental variables such as climate, satellite sensor data, elevation, slope, land use and land cover, soil type, and other map data are overlaid on a base map of standard geographic projection and scale. This study was designed to develop environmental parameters for mapping and predicting suitable habitats for bulinid species in disease endemic areas.

\section{Materials and methods}

Coordinates of the sampling sites were determined using a GPS (Magellan Explorist 310, MiTAC

Digital Corporation, CA 95050 USA). The study was carried out in Yewa North Local

87 Government Area (YNLGA), a local schistosomiasis transmission site in southwestern Nigeria (latitudes 6 $6^{\circ} 2^{\prime} 08^{\prime \prime} \mathrm{N}$ to $7^{\circ} 25^{\prime} 28^{\prime}$ ' $\mathrm{N}$ and longitudes $2^{\circ} 43^{\prime} 09^{\prime}$ 'E to $3^{\circ} 07^{\prime} 13$ ' 'E). It has a land size of about $200,214 \mathrm{~km}^{2}$. It shares boundaries with Imeko-Afon local government area in the North,

90 Yewa South Local Government Area in the South, Republic of Benin in the West and Abeokuta

91 North and Ewekoro local government areas in the East.

\section{Data collection}


94 Yewa North LGA has the largest landmass in Ogun State with forty-nine identified villages, each 95 village having water contact sites. Each of the villages were visited for snail sampling before the study started. Water contact sites without snail species were excluded from the study. After initial

97 pre-sample collection, a total of twenty-three water contact sites were randomly selected for snail 98 collection and analysis. Once in a month, bulinid species (Bulinus globosus, Bulinus jousseaumei, Bulinus camarunensis, Bulinus senegalensis and Bulinus forskalii) were collected from water contact sites using scoop net for two years. Snail identification and infection status were done using morphology and molecular methods respectively. Results of the snail identification and

The monthly spatial rainfall data was obtained from the European Meteorology Research Program (http://apps.ecmwf.int). The dataset has a spatial resolution of 0.7 meters. The data was downscaled using the multi-dimensional tool in ArcGIS software. NDVI was generated using the near infra-red band and the red Band. The value of the NDVI ranges from -1 to 1 , values lesser than 1 shows that the areas are not vegetated while vegetation condition improves has it tends to 1. The Digital Elevation Model (DEM) of the Advanced Space-borne Thermal Emission Radiometer (ASTER) was obtained from the National Aeronautical and Space Agency (NASA) host. The Slope image was obtained from the Digital Elevation Model and was converted using the spatial analyst tool in the ArcGIS. The slope was grouped into various classes ranging from the very steepy to flat. The unit of the slope was measured in percentage. The thermal band (10.4$12.5 \mu \mathrm{m})$ of Landsat ETM+ sensor was used to derive Land Surface Temperature over the study area. For the Landsat $\mathrm{ETM}^{+}$sensor, images in the thermal band were captured twice: once in the low-gain mode (band 6L) and once in the high-gain mode (band 6H). (30).

119 Logistic regression model was used as a method to investigate all potential explanatory variables 120 that may be important contributing environmental factors for estimating the location of snail 121 species. Independent variables such as spatial rainfall, slope, Normalized difference vegetation 122 Index (NDVI), and Land surface temperature (LST) were used while the different snail species 123 serve as the dependent variables. After careful considerations of the theory and examination of 
124 the data using the exploratory regression method, one model presented itself as most suitable for

125 predicting the locations of the snails. The model generates the equation as shown below:

$$
\mathrm{Y}=\beta_{0}+\beta_{1} \mathrm{X}_{1}+\beta_{2} \mathrm{X}_{2}+\ldots \beta \mathrm{nXn}+\varepsilon
$$

127 Where, $\mathrm{Y}=$ Dependent variable, $\mathrm{X}=$ Explanatory variable e.g environmental factors, Intercept $=\left(\beta_{0}\right)$,

128 Coefficients $=\left(\beta_{1} \ldots \beta n\right)$, Residuals $=(\varepsilon)$

129 The probability map was generated for each of the snail species with values ranging from 0 to 1.

$$
P=\frac{1}{1-\mathrm{e}^{\mathrm{z}}}
$$

131 Where, $\mathrm{P}=$ probability of occurrence, $\mathrm{e}=$ exponential, $\mathrm{z}=$ regression model obtained from the OLS

$132\left(\mathrm{Y}=\beta_{0}+\beta_{1} \mathrm{X}_{1}+\beta_{2} \mathrm{X}_{2}+\ldots \beta \mathrm{nXn}+\varepsilon\right)$

\section{Results}

135 Environmental factors used for building the model were extracted from the satellite imagery and 136 digital elevation model (Table 1). Slope of the area was categorized into flat (0.01-4.75), gentle 137 (4.76-9.23), moderate (9.24-15.83) and steepy (>15.84). Eastern areas had steepy slope while 138 southern areas were flat. Moderate NDVI was recorded in the south while the middle belt had 139 slightly lower NDVI values. Northern areas were higher compared to the south which were lower 140 in terms of elevation. LST were within the tolerance limit in the south while the north had higher 141 values. Spatial rainfall pattern were more in the north-west compared to south-east.

143 Table 1: Minimum and Maximum values of environmental variables

\begin{tabular}{ll}
\hline Environmental variables & Minimum and Maximum values \\
\hline Slope & $0.01-67.26$ \\
NDVI & $0.02-0.52$ \\
Elevation $(\mathbf{m})$ & $1.0-278$ \\
LST $\left({ }^{\circ} \mathbf{C}\right)$ & $21.1-27.7$ \\
Spatial Rainfall $(\mathbf{m m})$ & $1,569.34-1,590.02$ \\
\hline
\end{tabular}

144

145 Predictive model showed that most areas in YNLGA were suitable for the survival of B. globosus 146 except some middle belt. The logistic binary regression analysis showed that temperature, NDVI 147 and slope were the three major significant variables in predicting the geo-spatial distribution of $B$. 
globosus $(\mathrm{P}<0.05)$. The passing model using the $\mathrm{R}$ square and Akaike's Information Criterion (AICC) identified Imasayi, Ijoun, Oja-Odan, Oja-Ota and Ijale- Ketu as major areas where $B$. globosus can survive. A predictive risk map of B. globosus habitat was created based on the final logistic binary regression analysis (Figure 1). High risk areas were mainly located in Imasayi, Ijoun, Oja-Odan, Oja Ota and Ijale-Ketu while low risk areas were Ijaka, Sawonjo and Ibese. The binary logistic model of the probability of presence of $B$. globosus is stated below:

Predictive risk model of $B$. globosus habitats $=$

1

$\overline{\{1+\operatorname{Exp}[-(-132.202 * \text { Temperature })-(706.48 * N D V I)+(10.14961 * \text { Slope })]\}+3224.639}$

The predictive risk map of B. jousseaumei followed the same pattern as B. globosus, however, the predictive risk map of $B$. jousseaumei had higher R square value of $81 \%$. Temperature, NDVI and slope were the major variables used in the analysis $(\mathrm{P}<0.05)$. A predictive risk map of habitat was created based on the final binary logistic regression analysis (Figure 2).

The binary logistic model of the probability of $B$. jousseaumei is stated below:

Predictive risk of $B$. jousseaumei habitats $=$

$\frac{1}{\{1+\operatorname{Exp}[-(-71.8093 * \text { Temperature })-(439.156 * N D V I)+(8.613307 * \text { Slope })]\}+1744.694}$

Most of the areas in Southeastern part of YNLGA were suitable for the survival of B. senegalensis except some areas in the northwest. The logistic binary regression analysis showed that rainfall, NDVI and slope were the major spatial variables used in the model $(\mathrm{P}<0.05)$. Areas around Imasayi, Igbogila, Oja-Odan, Mosan, Owode, and Ebute-Igboro were identified as suitable for the survival of B. senegalensis. A predictive risk map of habitats was created based on the final binary logistic regression analysis (Figure 3).

Predictive risk of $B$. senegalensis habitats $=$

$\frac{1}{\{1+\operatorname{Exp}[-(0.766137 * \text { Rainfall })-(55.1167 * N D V I)+(1.330056 * \text { Slope })]\}-1199.128}$

Figure 4 showed the predictive risk map of B. camerunensis. The northern parts of the YNLGA were not suitable for the survival of $B$. camerunensis while most areas in the south were suitable for the survival of the species. The following variables: elevation, temperature, rainfall and slope 
177 were maintained in the analysis $(\mathrm{P}<0.05)$. The passing model using the $\mathrm{R}$ square $(99.2 \%)$ and 178 Akaike's Information Criterion (AICC) identified Eggua, Ijale-Ketu, Imoto-Odan, Igbogila, Agbon 179 and some other areas with the same digital value as suitable areas where B. camerunensis can 180 survive. The binary logistic model of the probability of the presence of B. camerunensis is stated 181 below:

182 Predictive risk of $B$. camerunensis habitats =

$183 \frac{1}{\{1+\operatorname{Exp}[-(0.43464 * \text { Elev })+(19.3684 * \text { Temp })-(0.49922 * \text { Rain })-(0.97732 * \text { Slope })]\}+350.1475}$ 184

185 The logistic regression analysis showed that NDVI and slope were the two significant variables in 186 predicting the geo-spatial distribution of $B$. forskalii $(\mathrm{P}<0.05)$. The passing model using the $\mathrm{R}$ 187 square (82.9\%) and Akaike's Information Criterion (AICC) identified Ibayun, Mosan, Ebute, Imo188 Odan and Tobolo as some of the major areas where B. forskalii can survive. A predictive risk map 189 of the habitat was created based on the final binary logistic regression analysis (Figure 5). The 190 binary logistic model of the probability of the presence of B. forskalii is stated below:

191 Predictive risk of $B$. forskalii habitats $=$

192

$$
\frac{1}{\{1+\operatorname{Exp}[-(-34.2399 * N D V I)+(0.604485 * \text { Slope })]\}+7.641222}
$$

193 


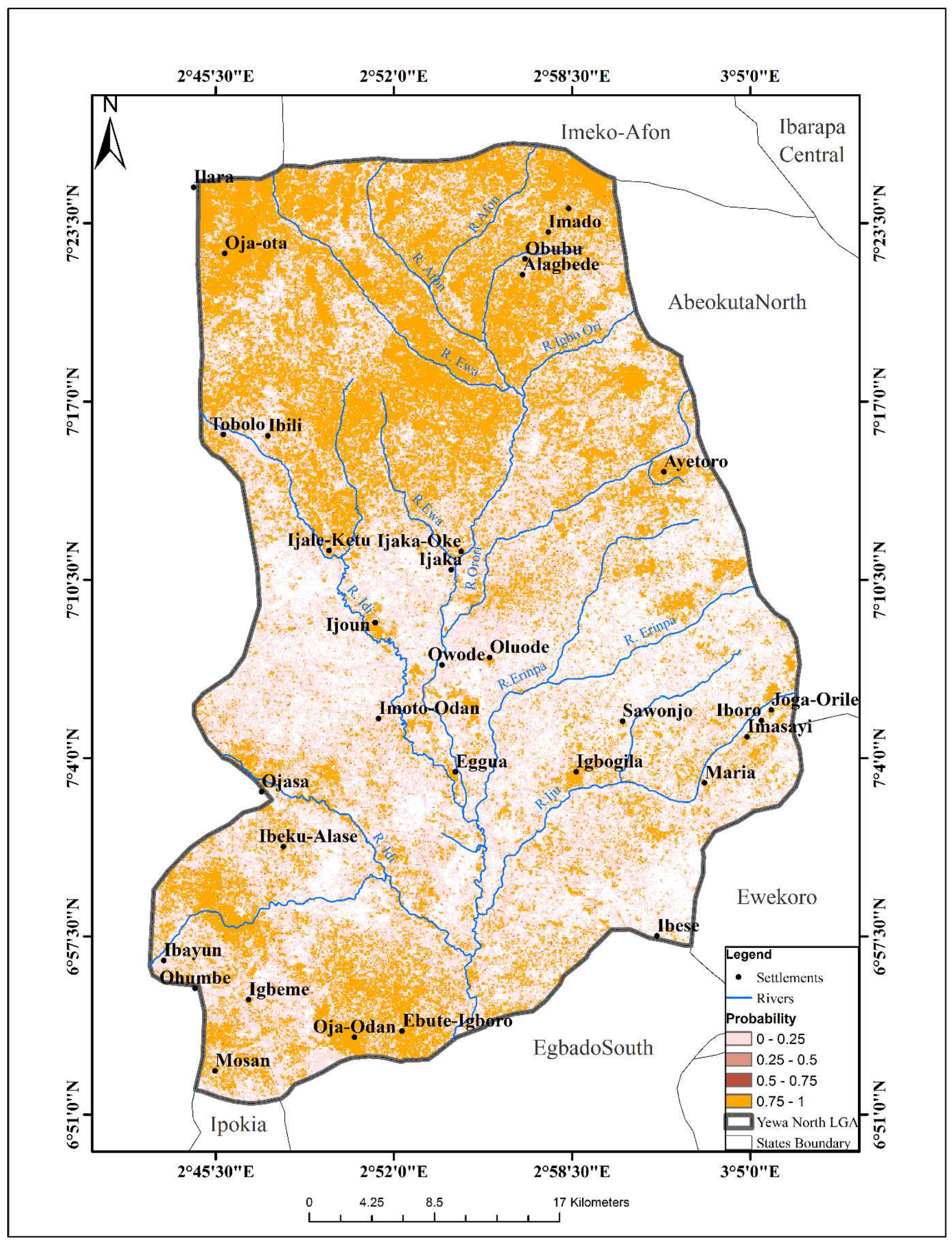




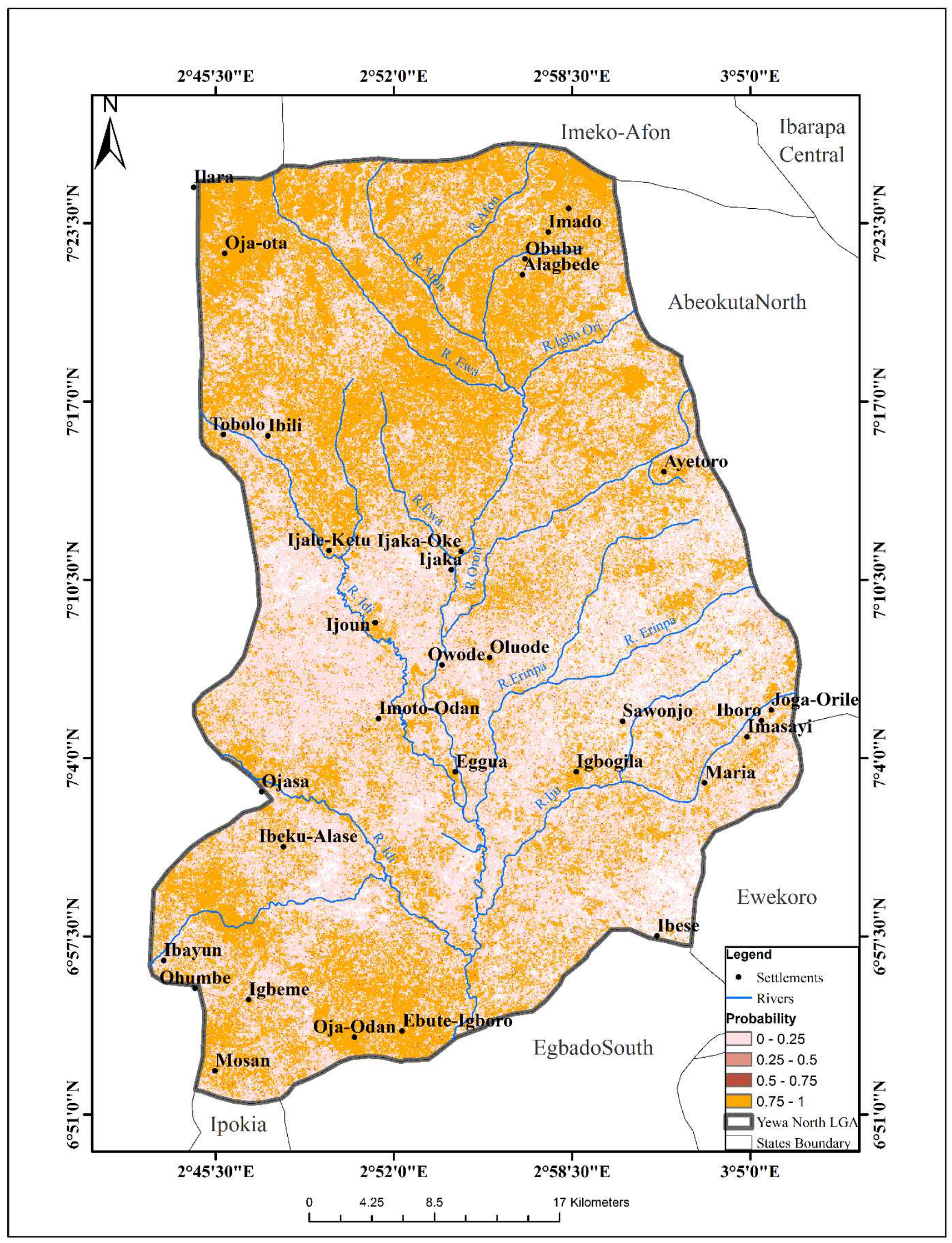

198

199 Fig. 2: Predictive Risk Map of Bulinus jouseaumei Habitat 


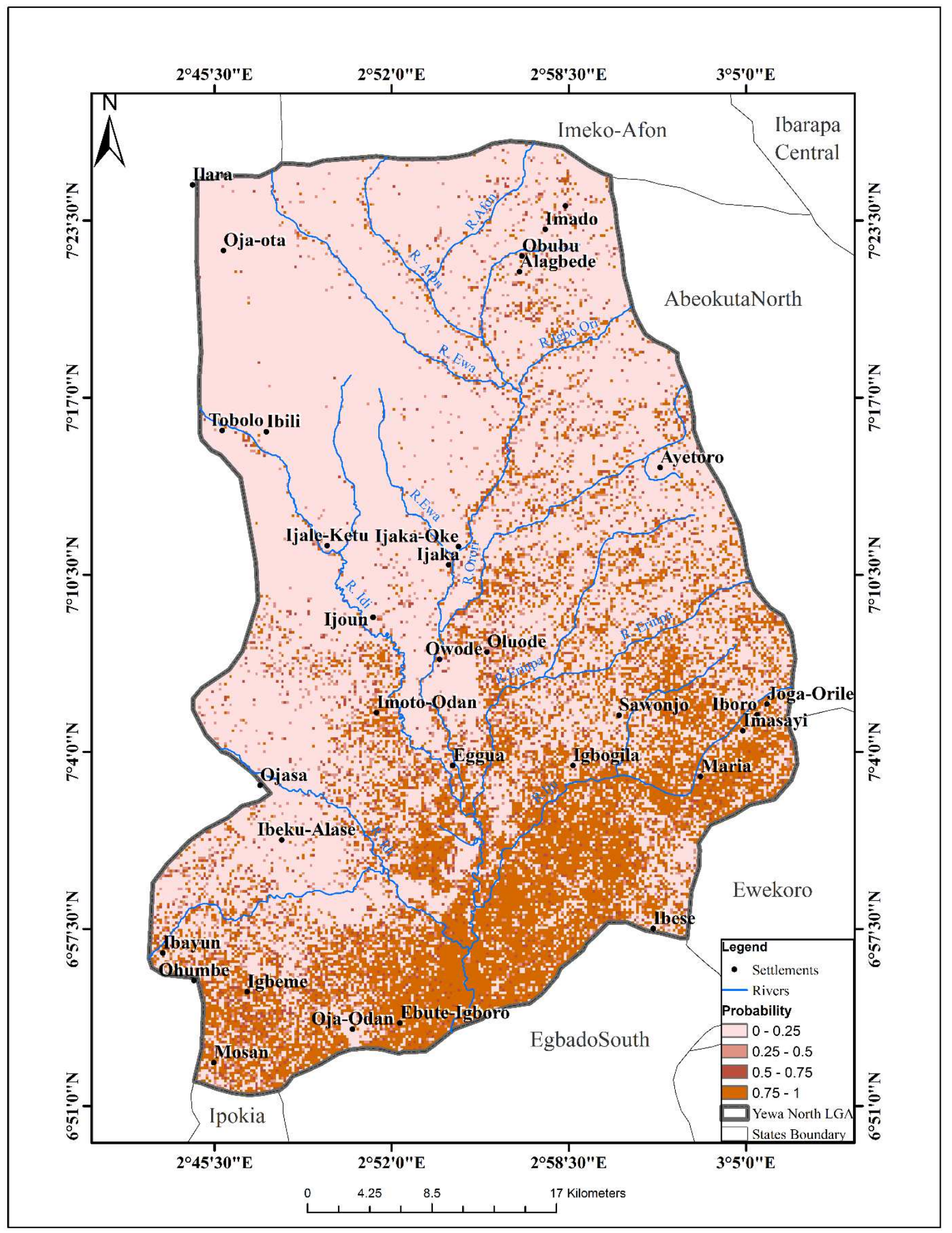

Fig. 3: Predictive Risk Map of Bulinus senegalensis Habitat 


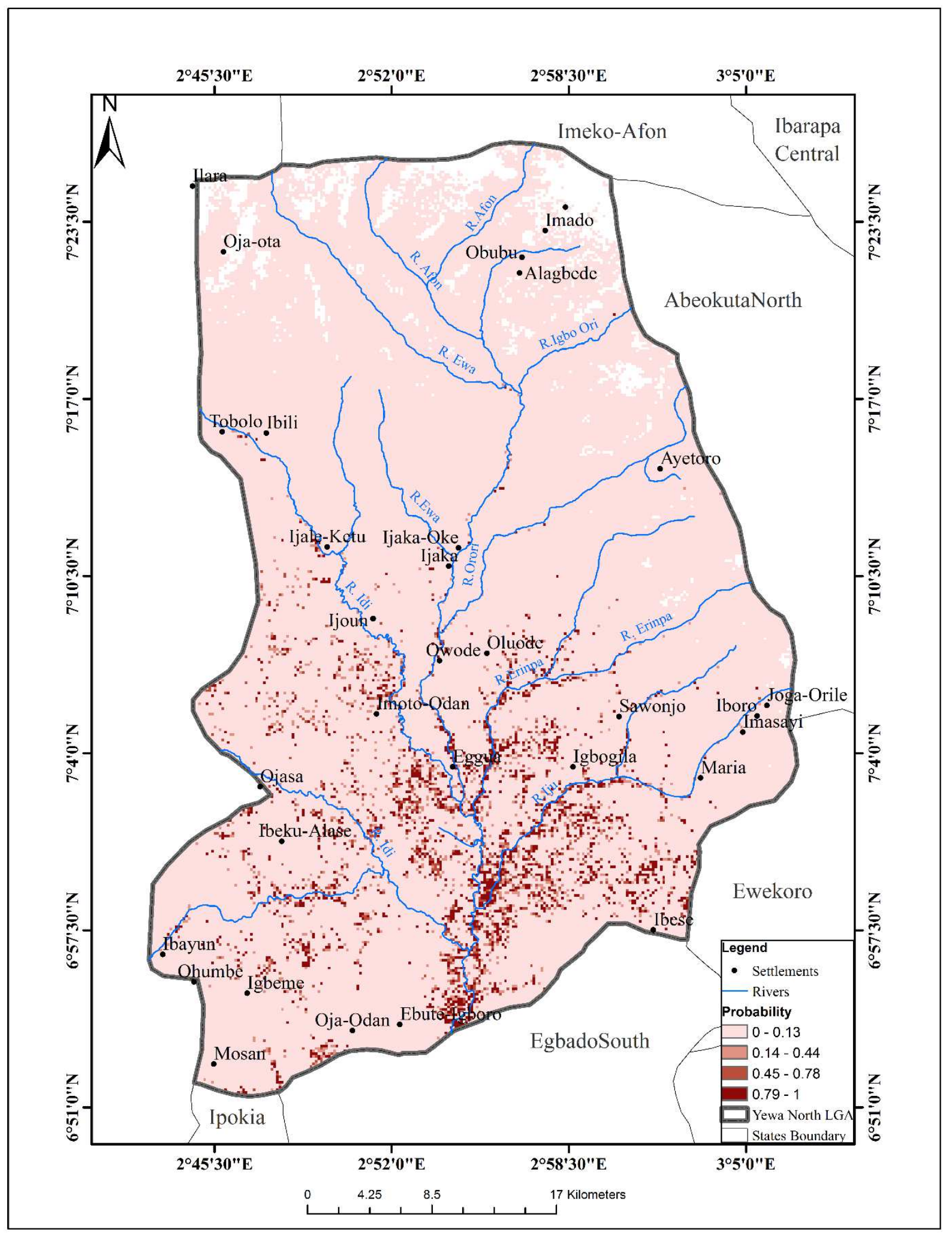

Fig. 4: Predictive Risk Map of Bulinus camerunensis Habitat 


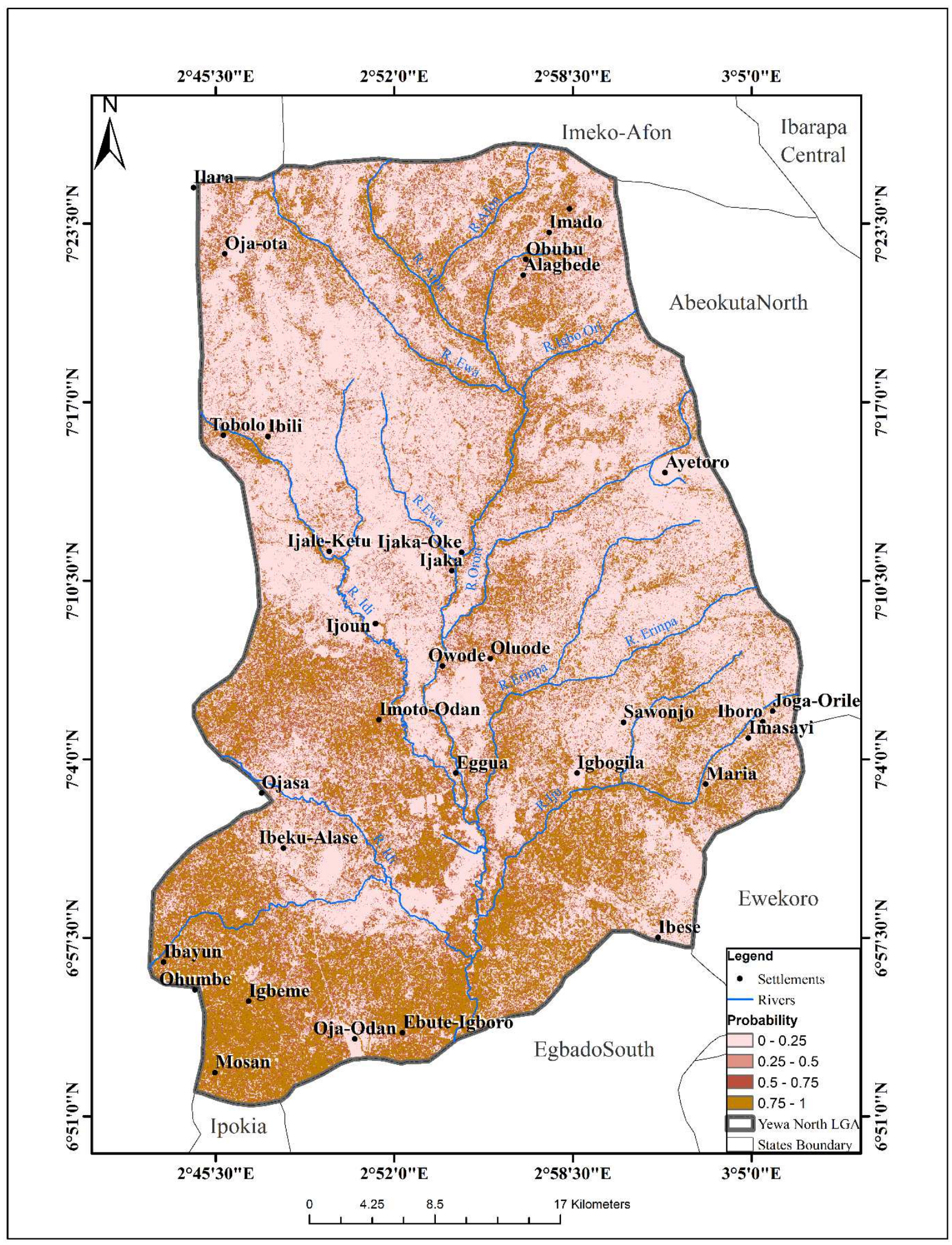

Fig. 5: Predictive Risk Map of Bulinus forskalii Habitat 


\section{Discussion}

209 Our study used the knowledge of GIS technology and dependent variables to create a model which

210 will be useful in monitoring the survival of snail intermediate host in areas where data collection

211 could be problematic. The application of GIS and remote sensing in science based study is of

212 tremendous importance in disease mapping and prediction, most especially in non-sampled areas

213 (31). The use of GIS/RS have been successfully used for predictions in some parts of African

214 countries $(32,33,34,35)$. Our study found that a larger percentage of the study area had NDVI of

215 between 0.19 and 0.52 , indicating the presence of vegetation cover and human activities. The

216 negative association observed between the NDVI and most of the bulinids was in deviance with

217 other studies conducted in Brazil and China (36-38), however, it was in consonance with other

218 observations elsewhere (39). The negative relationship suggests that there is a gradual increase in

219 anthropogenic activities in these areas. Vegetation and humidity are important environmental

220 parameters for snail intermediate hosts prediction. NDVI is an important vegetation index and has

221 been used in predicting the habitat of freshwater snail intermediate host of schistosomes in

222 different ecological zones $(34,40,41)$. At meso-scale, such as village survey, a moderate NDVI

223 and high wetness could increase the survival of snail intermediate host in an area while a low

224 NDVI values indicate the absence of water, and thus a lower probability of suitable snail habitats

225 suitable snail habitats $(37,42,43)$. For macro-scale such as country survey, a higher NDVI values

226 indicate a relatively higher vegetation cover, possibly increasing the probability of potential snail

227 intermediate host habitats (37).

228 The spatial rainfall data for the study area was within limits; hence, it appeared favourable for the 229 survival of freshwater snail intermediate host. The positive correlation between spatial rainfall data 230 and most of the snail intermediate host was in agreement with other study in Cross River State 231 (44). Rainfall is one of the major climatic conditions that influence the distribution and abundance 232 of snails and the rate of schistosomal development in the snail hosts $(45,46)$. In our study, the 233 optimum LST suitable for snail intermediate host to thrive very well is between $21.1^{\circ} \mathrm{C}$ and $23.4^{\circ} \mathrm{C}$, 234 other LST above $23.5^{\circ} \mathrm{C}$ seems to be lethal to intermediate snail hosts. The significant positive 235 relationship between LST and some of the bulinids was in deviance to other studies (38). However, 236 in Tanzania, no significant relationship occurred between LST and snail population (39). 237 Freshwater snail intermediate host of schistosomes have well defined land surface temperature for 238 optimal development. Land Surface Temperature was one of the determinant factors that affect the 
transmission dynamics of schistosome infection; it is known to influence the rate of miracidia

240 penetration, shedding of cercaria and the length of the pre-patent infection period (47). A study in

241 Ethiopia showed that satellite derived LSTs of $20-33^{\circ} \mathrm{C}$ values were able to define the distribution

242 of schistosoma prevalence (35). However, in Uganda, by contrast, no association was observed

243 between the prevalence of schistosomes and LST (32).

Apart from the northern part of the study area, elevation values were within the tolerance range for snail species to survive. Landscape pattern analysis can provide indications whether an area offers suitable habitats for snail intermediate host to survive. Repeated analyses and inference from comparable settings might also enable prediction of changes in the snail population resulting from ecologic transformation caused by human activities $(48,49)$ or deliberate targeted interventions for snail control. From our study, slope $\leq 4.75$ enhances the survival of snail intermediate host while slope $\geq 15.83$ may not provide a suitable habitat for snail intermediate host. The positive association that occurred between slope and most of the bulinid was in consonance with some findings in eastern Africa $(37,50)$. Low/flat areas had a positive effect with respect to risk of schistosoma infection in China (37). In another study, inhabitants of a village situated on steep slopes were at a lower risk of schistosoma infection compared to people living in plain areas, this was due to the fact that the plain areas were more economically advanced, and most people were attracted to those areas (51). Water bodies found in high sloppy areas are often characterized with high water flow velocity, which does not hold the water, and the fast flow could be too fast for intermediate host to maintain their existence in such areas. Therefore, the possibility for freshwater snail to colonize and survive in such area decreases as the slope increases (52). The following bulinids (B. senegalensis, B. camerunensis and B. forskalii) had higher probability of surviving in meddle belt and southern part of the study area. These three bulinids belong to the forskalii group and observation from the environmental variables which contributed to their habitat prediction, in different combination, could be as a result of the tolerance level of the environmental variables (LST, spatial rainfall, NDVI, slope and elevation). LST did not contribute to the building model for B. forskalii and B. senegalensis, indicating their low tolerance for high LST. The predictive risk model for B. jousseaume $i$ was similar to the pattern described for B. globosus. This could be because the two species are sympatric. The following environmental factors (LST, NDVI 
270 camerunensis, the ability of LST to form part of the building model for B. globosus and B.

271 jousseaumei, could be as result of the ability of the two species to adapt to high LST. In Nigeria,

272 bulinid species in forskalii group and B. jousseaumei are not widely reported, however, B. globosus

273 is cosmopolitan in every areas where Schistosoma haematobium is prevalent. The ability of $B$.

274 globosus to survive in some areas in our present study could be traced to long term adaptation of

275 the species to different ecological zones, however, the species were not found in higher elevated

276 areas $(>250)$. In conclusion, this study provides a more appropriate approach to identifying a

277 combination of environmental variables in modeling the habitat suitable for the survival of bulinid

278 species. Hence, our predictive risk map could serve as a guide for effective utilization of scares

279 resources in the control of schistosomiasis. Lack of advance satellite imagery for this study is one

280 of our major limitation. Availability of imagery such as GeoEye and WorldView will give more

281 detailed data for better analysis

282

283 Acknowledgements

284 We are also grateful to the head of Communities in Yewa North LGA, Ogun State.

285

\section{Author's contributions}

287 OAB conceived the idea; OGO carried out the sampling procedure, literature review and drafted 288 the first version of the paper. Both authors read, contributed and approved the paper.

\section{$290 \quad$ Funding}

291 The authors acknowledge the financial support from Wellcome ${ }^{\text {Trust }}$ Funded Institute of Infectious

292 Disease of Poverty (IIDP) given to OGO.

294 Ethics approval and consent to participate

295 We obtained an approval to carry out this study from Ogun State ministry of health. We also got 296 an approval from the village heads via thorough focus group discussion.

\section{Consent for publication}

299 Not applicable. 


\section{Competing interest}

302 The authors declare that they have no competing interests.

\section{Author's details}

${ }^{1,2}$ Parasitology Research Unit, Department of Zoology, Faculty of Science, University of Ibadan, Ibadan, Nigeria.

\section{References}

1. Brown DS. Freshwater Snails of Africa and Their Medical Importance, 2nd edn. . Taylor and Francis, London. 1994.

311 2. Rollinson D, Stothard J, C.S J, Lockyer AE, De Souza CP, Noble LR. Molecular 312 characterization of intermediate snail hosts and the search for resistance genes. Mem Inst Oswaldo 313 Cruz, 1998;93: 111-6.

314 3. Supian Z, Ikhwanuddin AM. Population dynamics of freshwater molluscs 315 (Gastropod:Melanoides tuberculata ) in Crocker Range Park, Sabah. ASEAN Rev Biodiv Environ 316 Conserv (ARBEC). 2002;1: 1.

317 4. Dundee DS, Paine A. Ecology of The Snail Melanoides tuberculata (Müller), Intermediate 318 Host of The Human Liver Fluke (Opisthorchis Sinensis) In New Orleans, Louisiana. The Nautilus 3191977 91:17-20.

320 5. Bogea T, Cordetro FM, Gouveja JS, . Melanoides tuberculatus (Gastropda: Thairidae) As 321 Intermediate Host of Heterophyidae (Trematoda: Digenea) In Rio Janeiro Metropolitan Area, 322 Brazil. . Rev Inst Med Trop S Paulo. 2005; 47: 87-90.

323 6. Brown DS. Freshwater Snails of Africa and Their Medical Importance 2nd eds. ed. 324 London: Taylor and Francis; 1994.

325 7. Rollinson D, Stothard JR, Southgate VR. Interactions between intermediate snail hosts of 326 the genus Bulinus and schistosomes of the Schistosoma haematobium group. Parasitology $327 \quad 2003 ; 123: 65-72$.

328 8. Phiri AM, Phiri IK, Chota A, Monrad J. Trematode infections in freshwater snails and 329 cattle from the Kufue Wetlands of Zambia during a period of highest cattle-water contact. Journal of helminthology 2007; 81: 85-92.

3319 9. Salawu OT, Odaibo AB. Schistosomiasis among pregnant women in rural communities in 332 Nigeria

333 Int J Gynecol Obstetrics. 2013; 122: 1-4.

334 10. Akinwale OP, Oso OG, Salawu OT, Odaibo AB, Chen PT, Gyang PV. Molecular 335 Characterization of Bulinus Snails Intermediate Hosts of Schistosomes in Ogun State, South West 336 Nigeria. Folia malacologia 2015;23: 1-11.

337 11. Chen MG. Use of praziquantel for clinical treatment and morbidity control of 338 schistosomiasis japonica in China: a review of 30 years' experience. Acta Tropa. 2005;96 168-76. 339 12. Zhang ZJ, Carpenter TE, Lynn HS, Chen Y, Bivand R, Clark AB, et al. Location of active 340 transmission sites of Schistosoma japonicum in lake and marshland regions in China. Parasitology $341 \quad 2009 ; 136: 737-46$. 
13. $\mathrm{Hu}$ Y, Zhang ZJ, Chen Y, Wang ZL, Gao J, Tao B, et al. Spatial pattern of schistosomiasis in Xingzi, Jiangxi Province, China: The effects of environmental factors. Parasites Vectors. 2013; 344 6: 214.

14. Reisen WK. Landscape epidemiology of vector-borne diseases. Annu Rev Entomol. 2010;55: 461-83.

15. Pavlovsky EN. Natural Nidality of Transmissable Diseases, with Special Reference to the Landscape Epidemiology of Zooanthroponse; . USA: University of Illinois Press: Urbana, IL. 1966.

16. Brooker S, Michael E. The potential of geographical information systems and remote sensing in the epidemiology and control of human helminth infections. Adv Parasitol. 2000; 47:245-88.

17. Malek ET. Snail hosts of schistosomiasis and other snail transmitted diseases in Tropical America. Washington: A Manual Scientific Publication, PAHO; 1985.

18. Ronquist F, Gardenfors U. Taxonomy and biodiversity inventories: time to deliver. Trends Ecol. Evol. 18:269 de Meeus T, Durand P, Renaud F. Species concepts: What for? Trend Parasitology 2003;

358 19: 425-7.

359 19. Beck LR, Rodriguez MH, Dister SW, Rodriguez AD, Washino RK, Roberts DR, et al. 360 Remote sensing as a landscape epidemiologic tool to identify villages at high risk for malaria transmission. . American Journal of Tropical Medicine and Hygiene 1994; 51:71-280.

20. Glass GE, Schwartz BS, Morgan JM, Johnson DT, Noy PM, Israel E. Environmental risk factors for Lyme disease identified with geographic information systems. American Journal of Public Health 1995; 85: 944-8.

21. Bernardi M. Linkages between FAO agroclimatic data resources and the development of GIS models for control of vector-borne diseases. Acta Tropica 2001;79:21-34.

22. Kistemann T, Dangendorf F, Schweikart J. New perspectives on the use of geographical information systems (GIS) in environmental health services. International Journal of Hygiene and Environmental Health 2002; 203: 301-10.

23. Bedard Y, Henriques WD. Modern information technologies in environmental health surveillance. An overview and analysis. Can J Public Health 2002; 93:29-33.

24. Bédard Y, Gosselin P, Rivest S, Proulx MJ, Nadeau M, Lebel G, et al. Integrating GIS Components with Knowledge Discovery Technology for Environmental Health Decision Support. . International Journal of Medical Informatics 2003; 70: 79-94.

25. Maantay J. Mapping environmental injustices: pitfalls and potential of geographic information systems in assessing environmental health and equity. Environ Health Perspect 2002; 110: 161-71.

26. Rytkönen M, Ranta J, Tuomilehto J, Karvonen M. Bayesian analysis of geographical variation in the incidence of Type I diabetes in Finland Diabetologia 2001; 44:37-44.

27. Rytkönen M, Moltchanova E, Ranta J, Taskinen O, Tuomilehto J, Karvonen M. The incidence of type 1 diabetes among children in Finland-rural-urban difference Health and Place. 2003;9: 315-25.

28. Berke EM. Geographic Information Systems (GIS): recognizing the importance of place in primary care research and practice. J Am Board Fam Med. 2010; 23: 9-12.

29. Bowman MA, Lupo P, Neale AV. Introduction of more editorial board members and google maps and google earth: the physician's cheap Geographic Information System (GIS). J Am

387 Board Fam Med. 2010; 23:4-5. 
30. Artis A. David, Carnahan H. Walter. Survey of emissivity variability in thermography of urban areas. RemoteSensing Environ. 1982; 12:313-29.

31. Hay SI. An overview of remote sensing and geodesy for epidemiology and public health application. Adv Parasitol. 2000;47:1-35.

32. Kabatereine NB, Brooker S, Tukahebwa EM, Kazibwe F, Onapa AW. Epidemiology and geography of Schistosoma mansoni in Uganda: implications for planning control. Trop Med Int Health 2004;9:372-80.

33. Malone JB, Abdel-Rahman MS, El Bahy MM, Huh OK, Shafik M, Bavia M. Geographic information systems and the distribution of Schistosoma mansoni in the Nile delta. Parasitol Today. 1997;

13: 112-9.

34. Raso G, Matthys B, N'Goran EK, Tanner M, Vounatsou P, Utzinger J. Spatial risk prediction and mapping of Schistosoma mansoni infections among school children living in western C^ote d'Ivoire. Parasitology. 2005;13:97-108.

35. Malone JB, Yilma JM, McCarroll JC, Erko B, Mukaratirwa S, Zhou XN. Satellite climatology and the environmental risk of Schistosoma mansoni in Ethiopia. Acta Tropica. 2001;79:59-72.

36. Simoonga C, Kazembe LN, Kristensen TK, Olsen A, Appleton CC, Mubita P, et al. The epidemiology and small-scale spatial heterogeneity of urinary schistosomiasis in Lusaka province, Zambia Geospatial Health. 2008;3:57-67.

37. Yang K, Zhou XN, Wu XH, Steinmann P, Wang XH, Yang GJ, et al. Landscape pattern analysis and bayesian modeling for predicting Oncomelania hupensis distribution in Eryuan county, People's Republic of China American Journal of Tropical Medicine and Hygiene. 2009;81:416-23.

38. Scholte RGC, Gosoniu L, Malone JB, Chammartin F, Utzinger J, Vounatsou P. Predictive risk mapping of schistosomiasis in Brazil using Bayesian geostatistical models. Acta Tropica. 2014;132:57-63.

39. Clements ACA, Brooker S, Nyandindi U, Fenwick A, Blair L. Bayesian spatial analysis of a national urinary schistosomiasis questionnaire to assist geographic targeting of schistosomiasis control in Tanzania, East Africa. International Journal for Parasitology 2008;38: 401-15.

40. Kristensen TK, Malone JB, McCarroll JC. Use of satellite remote sensing and geographic information systems to model the distribution and abundance of snail intermediate hosts in Africa: a preliminary model for Biomphalaria pfeifferi in Ethiopia Acta Tropica. 2001; 79:73-8.

41. Zhang ZY, Xu DZ, Zhou XN, Zhou Y, Sun ZD, Zhang B, et al. Application of satellite image for surveillance of vegetation landscapes of Oncomelenia-snail habitats in marshland using unsupervised classification Chin J Parasitol Parasitic Dis. 2003;24:261-4.

42. Bavia ME, Malone JB, Hale L, Dantas A, Marroni L, Reis R. Use of thermal and vegetation index data from earth observing satellites to evaluate the risk of schistosomiasis in Bahia, Brazil. Acta Tropica. 2001: 79:79-85.

43. Zhang ZJ, Ong S, Peng WX, Zhou YB, Zhuang JL, Zhao GM, et al. A model for the prediction of Oncomelania hupensis in the lake and marshland regions, China. Parasitol Int. 2008;57:121-131.

44. Adie HA, Okon OE, Arong GA, Ekpo UFB, ide EI. Environmental factors and distribution of urinary schistosomiasis in Cross River State, Nigeria. International Journal of Zoological Research 2014;10: 42-58. 
433 45. Appleton CC. Review of literature on abiotic factors influencing the distribution and life 434 cycle of bilharziasis intermediate host snails. . Malacological Review 1978;11:1-25.

435 46. Sturrock RF. The intermediate hosts and host-parasite relationships. In: Human 436 Schistosomiasis ( P. Jordan, G. Webbe and R.F. Sturrock) 2ed: CAB International, Wallingford. 437 1993; 33-85.

438 47. Anderson RM, Mercer JG, Wilson RA, Carter NP. Transmission of Schistosoma mansoni 439 from man to snail: Experimental studies of miracidial survival in relation to larval age, water 440 temperature, host size and host age. Parasitology. 1982; 85:339-60.

441 48. Steinmann P, Keiser J, Bos R, Tanner M, Utzinger J. Schistosomiasis and water resources 442 development: systematic review, meta-analysis, and estimates of people at risk. Lancet Infect Dis. 443 2006;6:411-25.

444 49. Li YS, Raso G, Zhao ZY, He YK, Ellis MK, McManus DP. Large water management 445 projects and schistosomiasis control, Dongting Lake region, China. Emerging Infectious Diseases. $446 \quad 2007 ; 13: 973-9$.

447 50. Schur N, Hürlimann E, Stensgaard A, Chimfwembe K, Mushinge G, Simoonga C, et al. 448 Spatially explicit Schistosoma infection risk in eastern Africa using Bayesian geostatistical 449 modeling. Acta Tropica. 2011;128:365- 77.

450 51. Steinmann P, Zhou XN, Li YL, Li HJ, Chen SR, Yang Z, et al. Helminth infections and 451 risk factor analysis among residents in Eryuan county, Yunnan province, China. Acta Tropica. $452 \quad 2007 ; 104$.

453 52. Zhu H, Liu L, Zhou X, Yang G. Ecological Model to Predict Potential Habitats of 454 Oncomelania hupensis, the Intermediate Host of Schistosoma japonicum in the Mountainous 455 Regions, China PLoS Negl Trop Dis. 2015;9:8. 


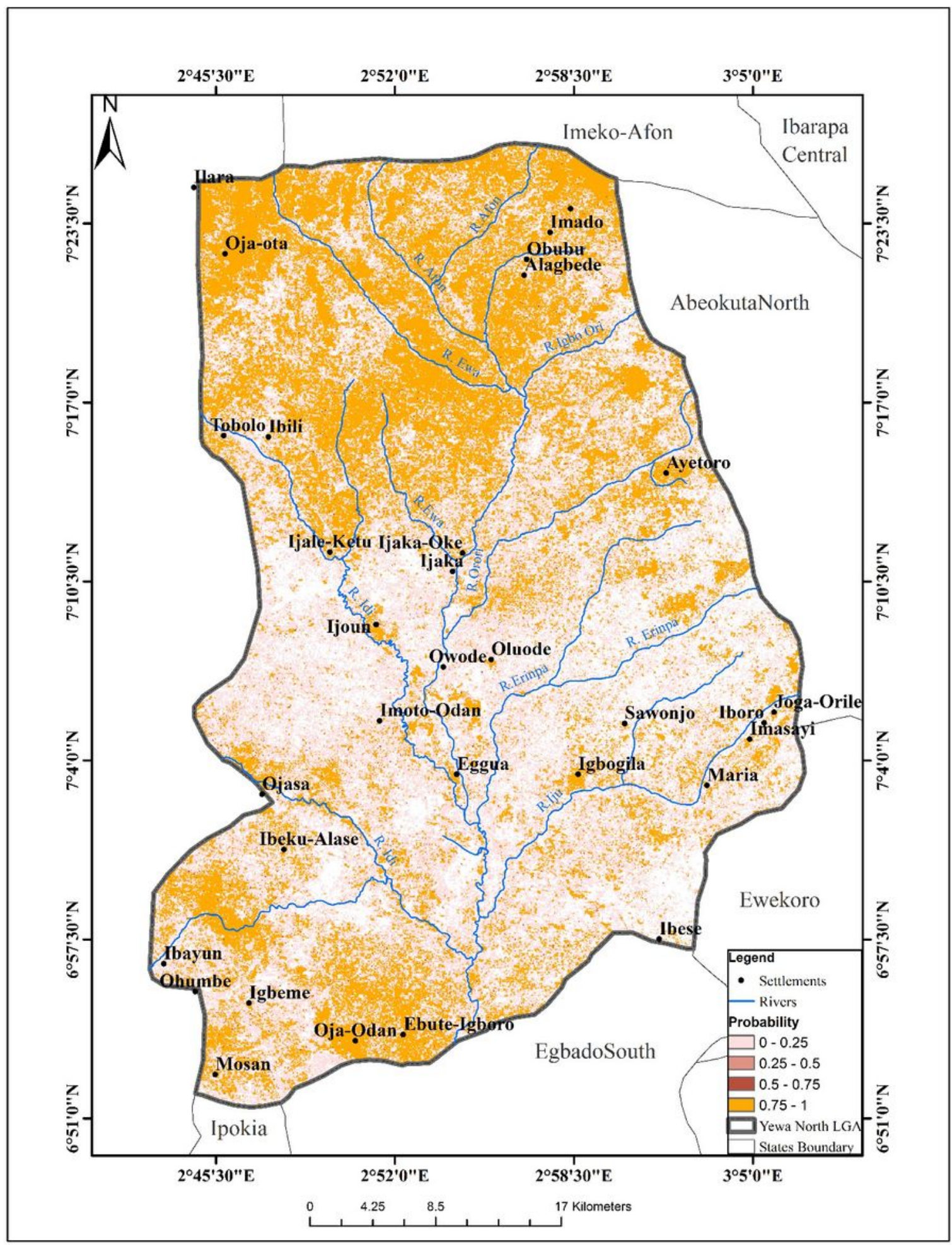

Figure 1

Predictive Risk Map of Bulinus globosus Habitat 


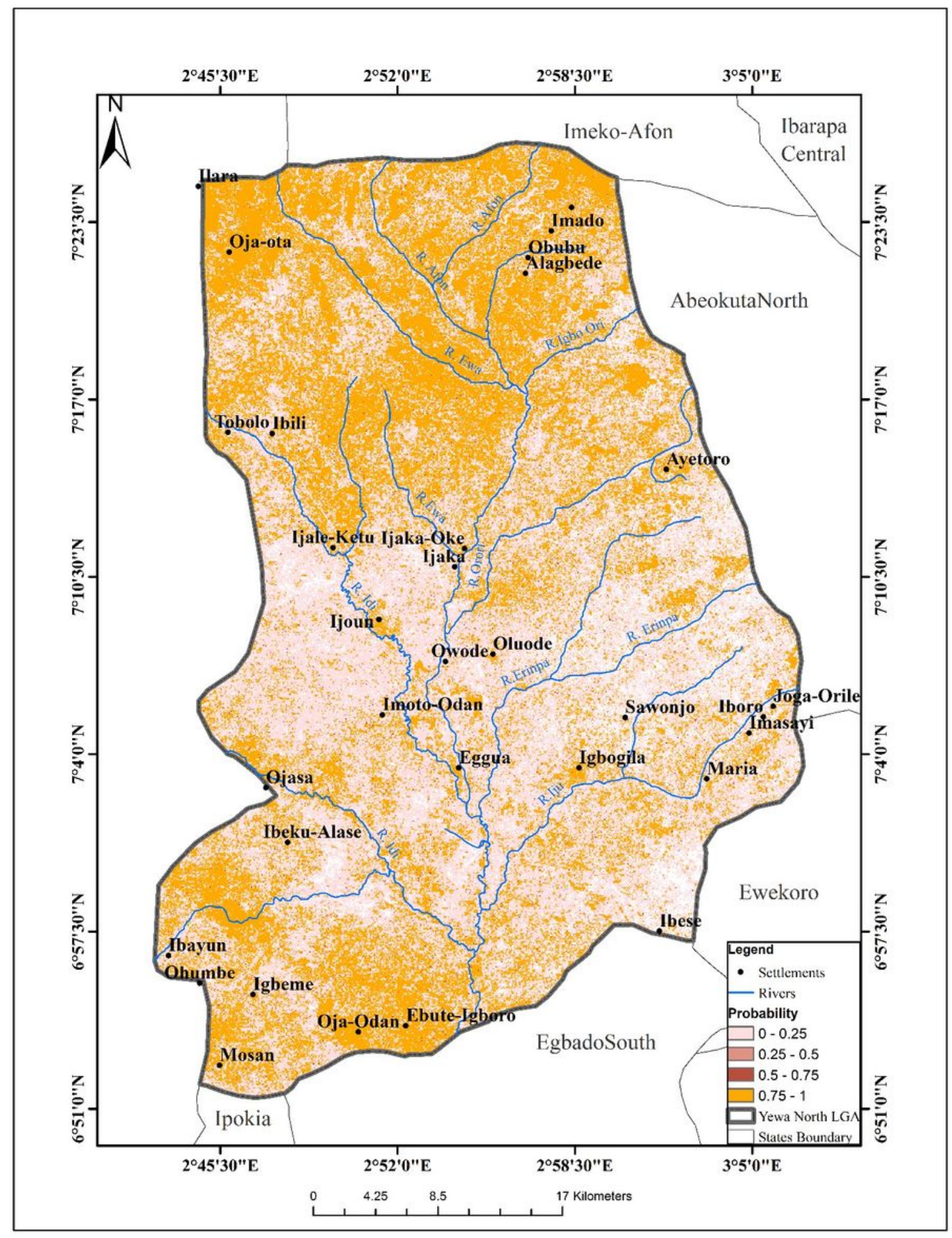

Figure 2

Predictive Risk Map of Bulinus jouseaumei Habitat 


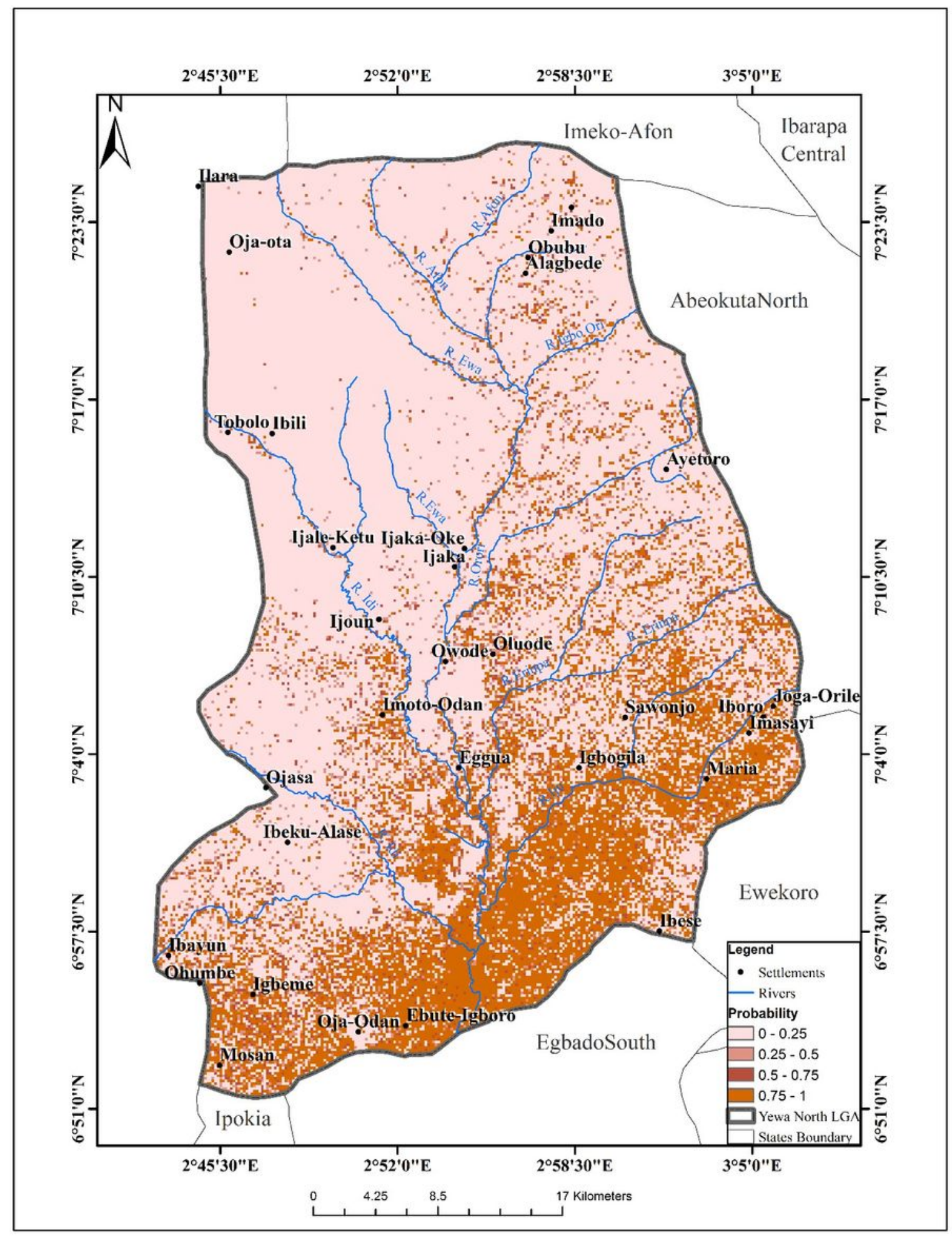

Figure 3

Predictive Risk Map of Bulinus senegalensis Habitat 


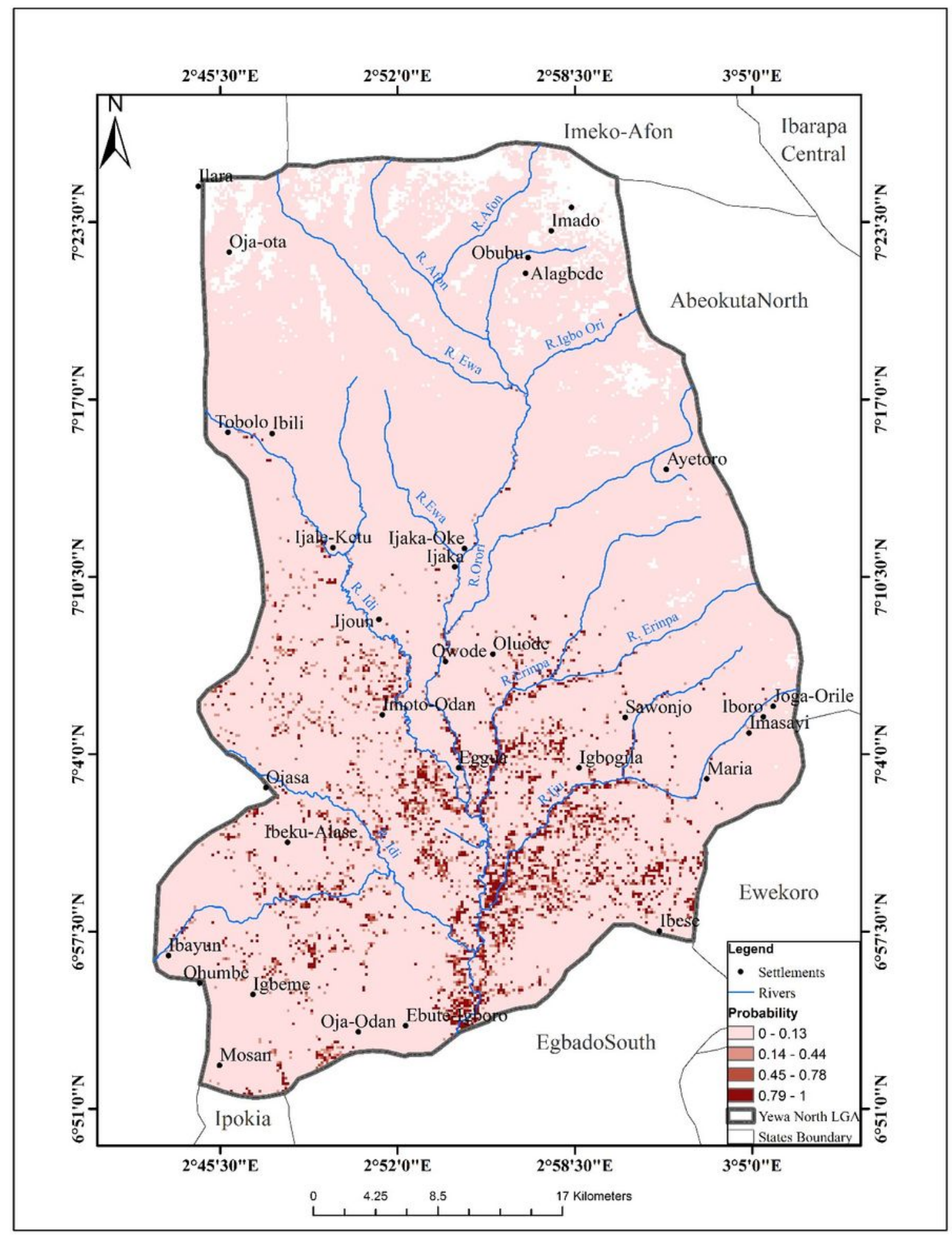

Figure 4

Predictive Risk Map of Bulinus camerunensis Habitat 


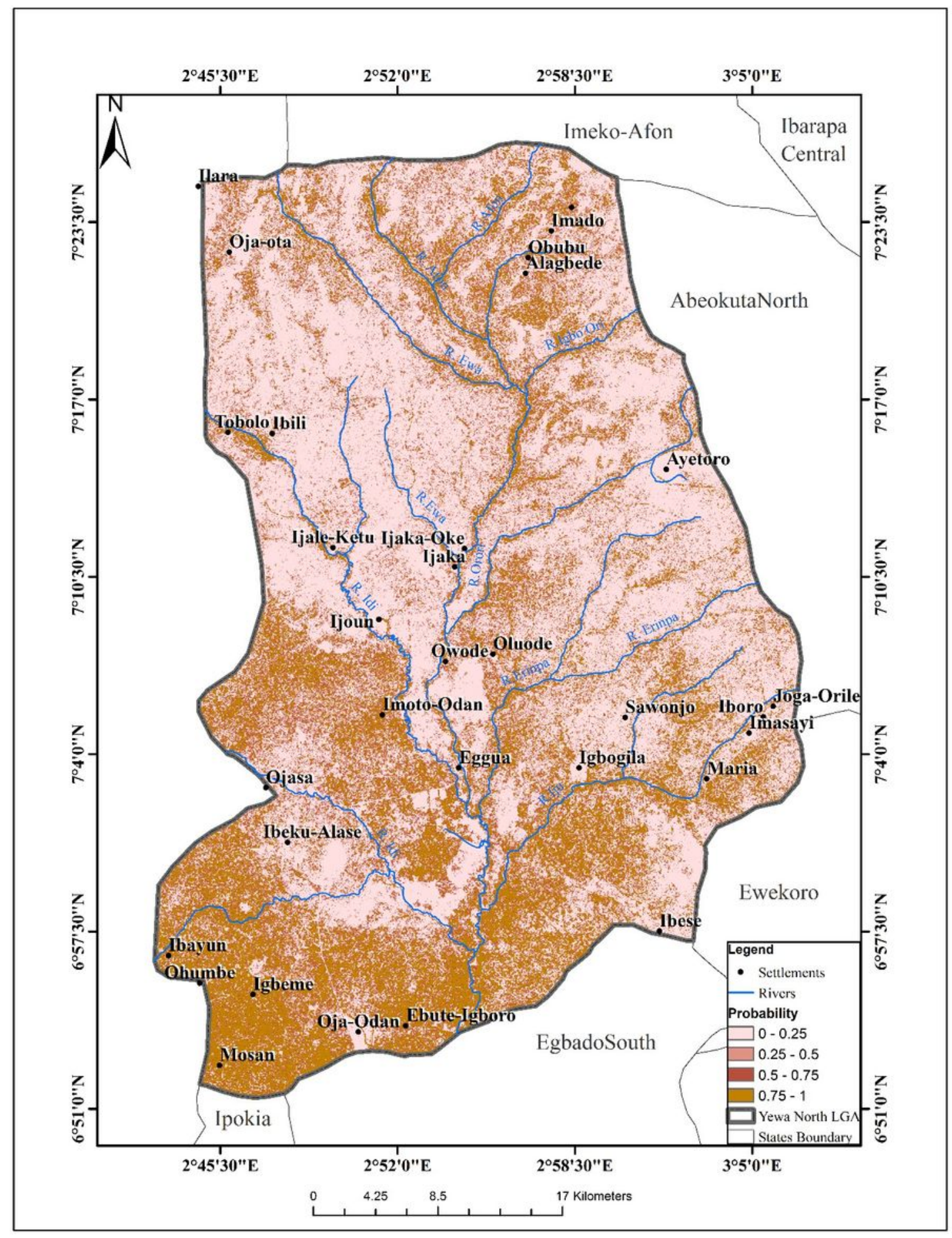

Figure 5

Predictive Risk Map of Bulinus forskalii Habitat 